\title{
Management of citrus leprosis using lime sulphur and their implications to soil and plant properties
}

\author{
Daniel Júnior de Andrade 1 , Fernando César Pattaro ${ }^{2}$, Mara Cristina Pessôa da Cruz \\ Matheus Rovere de Morais ${ }^{4}$, Cirano Cruz Melville ${ }^{5}$, Carlos Amadeu Leite de Oliveira ${ }^{6}$
}

Abstract - Lime sulphur is used worldwide in agriculture to control pests and diseases. Our objective was to determine the effect of lime sulphur applications in an orange orchard on soil chemical properties and foliar nutrients after seven years of use to control B. yothersi. Soil and leaf samples were collected in two consecutive years for determination of soil chemical properties and nutritional analysis, respectively. We also assessed severity of citrus leprosis and productivity of plants. The applications of lime sulphur reduced $\mathrm{pH}$ values in $\mathrm{CaCl}_{2}$ and increased levels of $\mathrm{S}_{-} \mathrm{SO}_{4}{ }^{2-}$ in subsurface soil layer. Plants treated with lime sulphur had the highest leaf concentrations of $\mathrm{Ca}$ and $\mathrm{S}$ and of the micronutrients $\mathrm{B}, \mathrm{Cu}, \mathrm{Mn}$ e $\mathrm{Zn}$. On the other hand, lime sulphur was able to reduce severity of citrus leprosis and had a positive effect on citrus productivity. The use of lime sulfur must be moderate, as the excessive use of this pesticide can cause imbalances in soil and plants, affecting the quality of food produced and causing negative impacts on the environment.

Index Terms: Brevipalpus yothersi, Citrus leprosis virus (CiLV), Citrus sinensis, Calcium polysulfide, Sulphur.

\section{Manejo da leprose dos citros com calda sulfocálcica e suas implicações sobre propriedades do solo e da planta}

Corresponding author:

danieldwv@yahoo.com.br

Received: December 13, 2019 Accepted: April 28, 2020

Copyright: All the contents of this journal, except where otherwise noted, is licensed under a Creative Commons Attribution License.

$(\mathrm{cc}) \mathbf{E Y}$
Resumo - A calda sulfocálcica é mundialmente utilizada na agricultura para controle de pragas e doenças. O estudo objetivou avaliar o efeito de aplicações de calda sulfocálcica em um pomar de laranja sobre as propriedades químicas do solo e nutrientes foliares após sete anos do uso para controle de $B$. yothersi. Amostras de solo e de folhas foram coletadas em dois anos consecutivos para a determinação das propriedades químicas do solo e análise nutricional, respectivamente. Além disso, avaliaram-se a severidade da leprose dos citros e a produtividade das plantas. As aplicações de calda sulfocálcica causaram redução nos valores de $\mathrm{pH}$ em $\mathrm{CaCl}_{2}$ e aumentaram os teores de $\mathrm{S}_{-} \mathrm{SO}_{4}{ }^{2-}$ em camadas subsuperficiais do solo. Plantas tratadas com calda sulfocálcica apresentaram maiores concentrações de $\mathrm{Ca}$ e $\mathrm{S}$ e dos micronutrientes $\mathrm{B}, \mathrm{Cu}, \mathrm{Mn}$ e $\mathrm{Zn}$. Por outro lado, a calda sulfocálcica foi capaz de reduzir a severidade da leprose e apresentou efeito positivo sobre a produtividade. O uso de calda sulfocálcica deve ser moderado, uma vez que o uso excessivo deste agrotóxico pode causar desequilíbrios no solo e nas plantas, afetando a qualidade dos alimentos produzidos e causando impactos negativos ao ambiente.

Termos para indexação: Brevipalpus yothersi, Citrus leprosis virus (CiLV), Citrus sinensis, Polissulfeto de cálcio, Enxofre.

\footnotetext{
${ }^{1}$ Assistant Professor (PhD) - College of Agricultural and Veterinary Sciences, São Paulo State University (FCAV/UNESP), Jaboticabal-SP, Brazil. E-mail: danieldwv@yahoo.com.br(ORCID 0000-0003-0054-879X)

${ }^{2}$ Assistant Professor (PhD) - Ingá University Center - UNINGÁ. Maringá-PR, Brazil. E-mail: fcpattaro@gmail.com ${ }^{\text {(ORCID: 0000-0003-1666-1009 }}$

${ }^{3}$ Assistant Professor (PhD) - College of Agricultural and Veterinary Sciences, São Paulo State University (FCAV/UNESP), Jaboticabal-SP, Brazil. E-mail: mcp.cruz@unesp.br(ORCID 0000-0002-6000-878X)

${ }^{4} \mathrm{PhD}$ - College of Agricultural and Veterinary Sciences, São Paulo State University (FCAV/UNESP), Jaboticabal-SP, Brazil. E-mail: matheusdemorais@yahoo.com.br ${ }^{\text {(ORCID 0000-0001-9909-7583) }}$

${ }^{5} \mathrm{PhD}$ - College of Agricultural and Veterinary Sciences, São Paulo State University (FCAV/UNESP), Jaboticabal-SP, Brazil. E-mail: ciranomelville@outlook.com ${ }^{\text {(ORCID 0000-0002-3794-5935) }}$

${ }^{6}$ Retired Professor - College of Agricultural and Veterinary Sciences, São Paulo State University (FCAV/UNESP), Jaboticabal-SP, Brazil. Email: amadeu.oliveira@unesp.br (ORCID 0000-0002-5901-1279)
} 


\section{Introduction}

In Brazilian citriculture, lime sulphur is used to control mites and scales, including citrus leprosis mite Brevipalpus yothersi Baker (Acari: Tenuipalpidae) (ANDRADE et al., 2011; MINEIRO et al., 2015). Citrus leprosis is a highly destructive disease caused by Citrus leprosis virus (CiLV-C), and it causes premature fruit drop, intense defoliation, branches drying, and in some situations, plant death (BASTIANEL et al., 2010).

Lime sulphur is an environmentally friendly organic material used worldwide for pest control in many crops (SMILANICK; SORENSON, 2001; HOLB et al., 2003; TUELHER et al., 2014). It is a mixture of calcium hydroxide and sulphur that results in calcium polysulfides as an active ingredient responsible for their toxicity of this pesticide (ABBOT, 1945; VENZON et al., 2013).

In Brazil, lime sulphur is mixed in water and applied to citrus plants at high-volumes (sometimes over 4,000 L ha-1) (PATTARO, 2003) allowing to reach the low mobility mite $B$. yothersi as this pesticide has a low residual effect (PATTARO, 2003). Nevertheless, during and after sprays, a significant volume of this pesticide reaches the soil (PATTARO, 2003; ANDRADE et al., 2010). We believe excessive use of lime sulphur can cause environmental changes in reason of the high concentration of $\mathrm{S}$ and $\mathrm{Ca}$ in spray solution. Therefore, the contents of these elements in the soil and plant can increase. Also, changes in soil $\mathrm{pH}$ values may occur (NGATUNGA et al., 2003; KARIMIZARCHI et al., 2014) and consequently alter the absorption of nutrients by the plant.

Understanding how lime sulphur affects soil and plant properties is important as this product is one of the few products authorized for use in organic agriculture and is it also an important tool in conventional production (SMILANICK; SORENSON, 2001). Thus, the study aimed to evaluate the effect of lime sulphur applications on soil chemical properties and foliar nutrients after several years of use to control B. yothersi.

\section{Materials and methods}

\section{Experimental area}

The study site was performed in a sweet orange orchard (Citrus sinensis L.) with the 'Pera' variety grafted onto 'Cleopatra' mandarins (Citrus reshni hort ex Tanaka) with citrus leprosis symptoms and occurrence of B. yothersi, in Reginópolis, São Paulo, Brazil (latitude $49^{\circ} 13^{\prime} 24^{\prime \prime} \mathrm{W}$ and longitude $21^{\circ} 56^{\prime} 26^{\prime \prime} \mathrm{S}$ ). The soil of the experimental area is classified as Red-Yellow Latosol (Oxisol) (EMBRAPA, 2013), and the region is classified as Cwa type subtropical with dry winter (Köeppen, 1970). At the beginning of experiment, the plants were 12 years old and drip irrigated. The experiment started in October 2003 and continued until February 2010, totaling seven years and four months of study.

\section{Experimental design and treatments}

Blocks were composed of two experimental groups: (i) lime sulphur, which included plots subjected to treatment with lime sulphur Super S20® (20\% elemental $\mathrm{S}$ and $8 \% \mathrm{Ca}$ ) and (ii) control, which included plots that did not receive lime sulphur or any other acaricide. The experimental design was completely randomized with 16 replications, in wich each replication consisted of three plants arranged in linear rows. Lime sulphur was applied in a concentration of 4 L p.c./100 L using a trailed sprayer coupled with Jacto handguns. Previously, the concentration was defined based on the work of Pattaro (2003), being sufficient to provide mite control without causing phytotoxicity. Applications had enough volume to provide adequate coverage of the plants $\left(4,000 \mathrm{~L} \mathrm{ha}^{-1}\right)$.

Lime sulphur applications were made according to $B$. yothersi population levels. Fruits from the interior of the plant canopy were collected, or in the absence of them, branches of $25 \mathrm{~cm}$ were taken. The fruits or branches were always removed from the central plant of each plot and examined for the presence of $B$. yothersi with a $10 \mathrm{X}$ magnification portable lens. The vector mite was monitored fortnightly.

Fruits and branches with at least one mite (except eggs) were considered infested for calculations of infestation level; the decision of spraying or not was made based on the action threshold, predetermined at $8.0 \%$ of infested fruit or branches. Throughout the experiment, it was necessary to have 31 lime sulphur applications to maintain the population of B. yothersi below $8.0 \%$. Therefore, approximately $992 \mathrm{~kg} \mathrm{ha}^{-1}$ of S and $396.8 \mathrm{~kg}$ $\mathrm{ha}^{-1}$ of Ca present in the lime sulphur were applied during the experiment. Five applications were performed in 2005 (March, April, June, August, and October), six in 2006 (January, March, May, June, August, and November), eight in 2007 (January, February, March, May, July, August, October, and November), seven in 2008 (January, February, March, May, June, September, and December), and five in 2009 (March, May, June, September, and December).

\section{Soil chemical parameters}

The samples were taken in February 2009 and 2010, during rainy season, in the projection area of plant canopy, at 0-20 and 20-40 cm soil layers. Each sample consisted of ten subsamples that were collected per plot using an auger tube type. The samples were collected in plots that received lime sulphur applications and in plots without application. The samples were air-dried, sieved through a 2 
mm mesh screen, and chemical attributes measured were: organic matter $(\mathrm{OM})$, active acidity $(\mathrm{pH})$, total acidity $(\mathrm{H}+\mathrm{Al})$, and available $\mathrm{P}, \mathrm{K}, \mathrm{Ca}$, and $\mathrm{Mg}$. Soil $\mathrm{pH}$ was measured in $0.01 \mathrm{~mol} \mathrm{~L}^{-1} \mathrm{CaCl}_{2}$ (1:2.5 soil: solution ratio, $\mathrm{v}: \mathrm{v})$ and $(\mathrm{H}+\mathrm{Al})$ in the SMP-buffer solution. Available $\mathrm{P}, \mathrm{K}, \mathrm{Ca}$, and $\mathrm{Mg}$ were extracted with ion exchangeable resins and quantified by colorimetry $(\mathrm{P})$, flame photometry $(\mathrm{K})$, and atomic absorption spectrometry $(\mathrm{Ca}$ and $\mathrm{Mg})$. By sum of $\mathrm{Ca}, \mathrm{Mg}$, and $\mathrm{K}$ was obtained the sum of bases ( $\mathrm{SB}), \mathrm{SB}+(\mathrm{H}+\mathrm{Al})$ resulted in the cation exchange capacity $\left(\mathrm{CEC}_{\mathrm{pH}}\right)$, and $\left[100\left(\mathrm{SB} / \mathrm{CTC}_{\mathrm{pH}}\right)\right]$, in the bases saturation (BS\%). S-SO ${ }_{4}^{2-}$ was extracted with $\mathrm{Ca}\left(\mathrm{H}_{2} \mathrm{PO}_{4}\right)_{2} \cdot \mathrm{H}_{2} \mathrm{O} 0.01$ mol L-1 and quantified using a turbidimetric method. All methods used are described in van Raij et al. (2001).

\section{Foliar nutrients evaluation}

Foliar nutrients evaluations were performed in February 2009 and 2010. In each experimental plot, eight leaves of the central plant were collected (two leaves per quadrant of the plant) and packed in paper bags. Leaves were collected from the middle region of the plant, always the third and fourth leaves from the fruit (MATTOS JUNIOR et al., 2005). In the laboratory, leaves were washed in $0.1 \%$ neutral detergent solution and $1 \%$ hydrochloric acid $(\mathrm{HCl})$ solution and finally in deionized water. The leaf samples were placed in paper bags and kept in a kiln at $60-70{ }^{\circ} \mathrm{C}$ for $72 \mathrm{~h}$ for drying. The foliar nutrient contents of the macro and micronutrients $(\mathrm{Ca}, \mathrm{Mg}, \mathrm{S}, \mathrm{K}$, $\mathrm{P}, \mathrm{N}, \mathrm{B}, \mathrm{Cu}, \mathrm{Fe}, \mathrm{Mn}$, and $\mathrm{Zn}$ ) were determined according to the methodology proposed by Malavolta et al. (1997).

\section{Severity of citrus leprosis}

Leprosis severity assessments were completed on all plants of the experiment between April and July of 2008 and 2009 because it is the time of year with the highest expression of the disease (RODRIGUES et al., 2003). For this, we used a visual grading scale as proposed by Rodrigues (2000), which ranges from zero (0) to five (5), as follows: (0) no lesions; (1) few injuries in any organ, restricted to one sector of the plant; (2) lesions in more than one organ and/or distributed in more than one sector; (3) abundant lesions in all organs and well distributed throughout the plant; (4) abundant lesions throughout the plant and fall of leaves and/or fruits, and (5) abundant lesions throughout the plant, leaf drop and/or fruits, and dried and death of branches. In the evaluation, each plant received two notes, given by different evaluators, being considered the average of the two notes for the data analysis.

\section{Productivity}

Fruits of all plants were harvested in September 2008 and October 2009 to determine productivity. The sampling point was determined based on the value of the maturation index or ratio (average ratio of 14). The fruits were weighed, and the value obtained per plot was extrapolated to kilograms per hectare $\left(\mathrm{kg} \cdot \mathrm{ha}^{-1}\right)$, considering the spacing between plants in the experimental area $(7 \times 4 \mathrm{~m})$.

\section{Cultural practices}

Cultural practices such as management of pests (except B. yothersi), diseases and weeds, fertilization, liming, and mechanized pruning were carried out normally in the experimental area.

\section{Data analysis}

Data on soil chemical parameters, foliar nutrients, citrus leprosis severity, and productivity were analyzed using an $F$-test in Agroestat software (BARBOSA and MALDONADO JUNIOR, 2015). A simple correlation was performed between data of the $\mathrm{pH}$ and $\mathrm{S}_{-} \mathrm{SO}_{4}{ }^{2-}$ using MS Excel (Microsoft Office, 2016).

\section{Results}

The soil samples collected from topsoil in 2009 in plots that received lime sulphur and in control showed significant differences in values of $\mathrm{pH}, \mathrm{Mg}, \mathrm{H}+\mathrm{Al}$, and $\mathrm{S}_{-} \mathrm{SO}_{4}{ }_{4}^{2-}$. The values of $\mathrm{pH}$ and $\mathrm{Mg}$ were higher for the control, while values of $\mathrm{H}+\mathrm{Al}$ and $\mathrm{S}_{-} \mathrm{SO}_{4}{ }^{2-}$ were higher for lime sulphur group. Organic matter $(\mathrm{OM}), \mathrm{P}, \mathrm{K}, \mathrm{Ca}$, and bases saturation (BS\%) were not significantly different in this evaluation. In 2009, the results from subsoil showed significant differences between experimental groups to values of $\mathrm{Mg}, \mathrm{H}+\mathrm{Al}$, Cation Exchange Capacity (CEC), and $\mathrm{S}_{-} \mathrm{SO}_{4}{ }^{2}$. The values of $\mathrm{Mg}$ were higher in control, while the values of $\mathrm{H}+\mathrm{Al}, \mathrm{CEC}$, and $\mathrm{S}_{-} \mathrm{SO}_{4}{ }^{2-}$ were higher in the lime sulphur treatment (Table 1). 
Table 1. Analyses results of soil collected in February 2009 (after six years) in the depths of $0-20 \mathrm{~cm}$ and $20-40 \mathrm{~cm}$.

Depth of 0-20 cm

\begin{tabular}{|c|c|c|c|c|c|c|c|c|c|c|}
\hline \multirow{3}{*}{ Groups } & \multirow{3}{*}{$\mathrm{pH} \mathrm{CaCl}{ }_{2}$} & & & & & & & & \multirow{3}{*}{$\begin{array}{c}\mathrm{S}^{-\mathrm{SO}_{4}}{ }^{2-} \\
\mathrm{mg} \mathrm{dm}^{-3}\end{array}$} & \multirow{3}{*}{ BS\% $\%^{3}$} \\
\hline & & $\mathbf{O M}^{1}$ & $\mathbf{P}($ resin) & $\mathbf{K}^{+}$ & $\mathrm{Ca}^{2+}$ & $\mathbf{M g}^{2+}$ & $\mathbf{H}+\mathbf{A l}$ & $\mathbf{C E C}^{2}$ & & \\
\hline & & $g \mathrm{dm}^{-3}$ & $\mathbf{m g ~ d m ^ { - 3 }}$ & \multicolumn{5}{|c|}{$\mathbf{m m o l}_{\mathbf{c}} \mathbf{d m}^{-3}$} & & \\
\hline Lime sulphur & $5.1 \mathrm{~b}$ & 15.1 & 33.5 & 1.5 & 17.0 & $7.1 \mathrm{~b}$ & $21.7 \mathrm{a}$ & 46.7 & $6.1 \mathrm{a}$ & 53.4 \\
\hline Control & $5.4 \mathrm{a}$ & 15.1 & 36.8 & 1.7 & 19.3 & $9.8 \mathrm{a}$ & $17.4 \mathrm{~b}$ & 47.4 & $4.3 \mathrm{~b}$ & 61.9 \\
\hline$F$-test & $5.8^{*}$ & $0.4^{\mathrm{ns}}$ & $2.6^{\mathrm{ns}}$ & $2.8^{\mathrm{ns}}$ & $0.7^{\mathrm{ns}}$ & $4.5^{*}$ & $6.4^{*}$ & $0.2^{\mathrm{ns}}$ & $24.3 * *$ & $3.7^{\mathrm{ns}}$ \\
\hline $\mathrm{CV}(\%)^{4}$ & 6.9 & 14.3 & 16.2 & 18.3 & 29.2 & 28.7 & 22.6 & 18.4 & 19.8 & 21.6 \\
\hline \multicolumn{11}{|c|}{ Depth of 20-40 cm } \\
\hline Lime sulphur & 4.3 & 11.1 & 10.9 & 1.0 & 5.6 & $2.8 \mathrm{~b}$ & $30.1 \mathrm{a}$ & $39.6 \mathrm{a}$ & $10.3 \mathrm{a}$ & 23.9 \\
\hline Control & 4.4 & 10.6 & 11.9 & 1.1 & 5.7 & $3.8 \mathrm{a}$ & $26.6 \mathrm{~b}$ & $37.2 \mathrm{~b}$ & $5.6 \mathrm{~b}$ & 28.3 \\
\hline$F$-test & $2.1^{\mathrm{ns}}$ & $0.7^{\mathrm{ns}}$ & $2.3^{\mathrm{ns}}$ & $1.3^{\mathrm{ns}}$ & $0.00^{\mathrm{ns}}$ & $9.7 * *$ & $7.9 * *$ & $4.9^{*}$ & $28.5^{* *}$ & $2.8^{\mathrm{ns}}$ \\
\hline $\mathrm{CV}(\%)^{4}$ & 5.0 & 15.9 & 22.4 & 21.7 & 29.8 & 28.7 & 12.4 & 7.9 & 27.6 & 28.4 \\
\hline
\end{tabular}

Averages followed by the different letter in the column differ significantly by $F$-test. ${ }^{1} \mathrm{OM}$ organic matter. ${ }^{2} \mathrm{Cation}$ Exchange Capacity. ${ }^{3}$ Percentage base saturation. ${ }^{4}$ Coefficient of variation. $(* *)$ significant at $1 \%$, and $(*) 5 \%$ of the probability.

Soil collected in 2010 in topsoil showed significant differences between control and lime sulphur groups in the values of $\mathrm{pH}, \mathrm{K}, \mathrm{Mg}, \mathrm{H}+\mathrm{Al}, \mathrm{S}_{-} \mathrm{SO}_{4}^{2-}$, and $\mathrm{BS} \%$. On the other hand, OM, $\mathrm{P}, \mathrm{Ca}$, and $\mathrm{CEC}$ were not significantly different in this evaluation. The values of $\mathrm{pH}, \mathrm{K}, \mathrm{Mg}$, and $\mathrm{BS} \%$ were higher for the control group, while the values of $\mathrm{S}_{-} \mathrm{SO}_{4}{ }^{2-}$ were higher in the lime sulphur group. In the subsoil, the values of $\mathrm{pH}, \mathrm{K}, \mathrm{Mg}$, and $\mathrm{BS} \%$ were higher for samples collected in the control group, while the values of $\mathrm{H}+\mathrm{Al}$ and $\mathrm{S}_{-} \mathrm{SO}_{4}{ }^{2-}$ were higher in the lime sulphur group (Table 2). However, there was no significant correlation between soil $\mathrm{pH}$ and $\mathrm{S}_{-} \mathrm{SO}_{4}{ }^{2-}$.

Table 2. Analyses results of soil collected in February 2010 (after seven years) in the depths of $0-20 \mathrm{~cm}$ and $20-40 \mathrm{~cm}$.

\begin{tabular}{|c|c|c|c|c|c|c|c|c|c|c|}
\hline \multirow{3}{*}{ Groups } & \multirow{3}{*}{$\mathrm{pH} \mathrm{CaCl}{ }_{2}$} & \multicolumn{8}{|c|}{ Depth of 0-20 cm } & \multirow{3}{*}{ BS\% ${ }^{3}$} \\
\hline & & & $\mathbf{P}($ resin) & $\mathbf{K}^{+}$ & $\mathrm{Ca}^{2+}$ & $\mathrm{Mg}^{2+}$ & $\mathbf{H}+\mathbf{A l}$ & $\mathrm{CEC}^{2}$ & \multirow{2}{*}{$\begin{array}{l}\mathrm{S}^{-\mathrm{SO}_{4}}{ }^{2-} \\
\mathrm{mgdm}^{-3}\end{array}$} & \\
\hline & & $\mathrm{g} \mathrm{dm}^{-3}$ & $\mathrm{mg} \mathrm{dm}{ }^{-3}$ & \multicolumn{5}{|c|}{$\mathbf{m m o l}_{c} \mathbf{d m}^{-3}$} & & \\
\hline Lime sulphur & $4.8 \mathrm{~b}$ & 16.2 & 32.4 & $1.4 \mathrm{~b}$ & 16.0 & $5.7 \mathrm{~b}$ & $24.1 \mathrm{~b}$ & 46.7 & $7.3 \mathrm{a}$ & $47.6 \mathrm{~b}$ \\
\hline Control & $5.2 \mathrm{a}$ & 16.2 & 36.1 & $1.8 \mathrm{a}$ & 18.4 & $7.4 \mathrm{a}$ & $26.1 \mathrm{a}$ & 46.3 & $4.3 \mathrm{~b}$ & $57.8 \mathrm{a}$ \\
\hline$F$-test & $10.4 * *$ & $0.0^{\mathrm{ns}}$ & $2.3^{\mathrm{ns}}$ & $1.1^{* *}$ & $1.7^{\mathrm{ns}}$ & $5.7^{*}$ & $12.5^{* *}$ & $0.05^{\mathrm{ns}}$ & $24.9 * *$ & $6.1^{*}$ \\
\hline C.V. $(\%)^{4}$ & 7.1 & 17.4 & 19.9 & 15.3 & 29.1 & 9.1 & 18.6 & 11.2 & 27.6 & 22.1 \\
\hline Groups & \multicolumn{9}{|c|}{ Depth of 20-40 cm } & \\
\hline Lime sulphur & $4.2 \mathrm{~b}$ & 11.8 & 10.7 & $1.0 \mathrm{~b}$ & 6.7 & $3.1 \mathrm{~b}$ & $30.4 \mathrm{a}$ & 40.9 & $17.4 \mathrm{a}$ & $26.0 \mathrm{~b}$ \\
\hline Control & $4.4 \mathrm{a}$ & 11.9 & 14.5 & $1.2 \mathrm{a}$ & 6.4 & $4.6 \mathrm{a}$ & $26.5 \mathrm{~b}$ & 39.8 & $6.5 \mathrm{~b}$ & $33.0 \mathrm{a}$ \\
\hline$F$-test & $10.4 * *$ & $0.1^{\mathrm{ns}}$ & $2.7^{\mathrm{ns}}$ & $9.2^{* *}$ & $0.2^{\mathrm{ns}}$ & $13.6^{* *}$ & $6.8^{*}$ & $1.0^{\mathrm{ns}}$ & $60.1^{* *}$ & $6.2 *$ \\
\hline C.V. $(\%)^{4}$ & 4.8 & 12.0 & 51.7 & 19.8 & 26.9 & 30.5 & 14.7 & 8.5 & 29.7 & 27.1 \\
\hline
\end{tabular}

Averages followed by the different letter in the column differ significantly by $F$-test. ${ }^{1} \mathrm{OM}$ organic matter. ${ }^{2} \mathrm{Cation}$ Exchange Capacity. ${ }^{3} \mathrm{Percentage}$ base saturation. ${ }^{4}$ Coefficient of variation. $(* *)$ significant at $1 \%$, and $(*) 5 \%$ of the probability. 
Regarding foliar macronutrients in 2009 , there was a difference between treatment with lime sulphur and control for N, P, K, Ca and S (Table 3). We found the levels of N, P and K in 2009 were higher in the control, while $\mathrm{Ca}$ and $\mathrm{S}$ were higher in the lime sulphur group. In 2010, the values of $\mathrm{K}$ and $\mathrm{Mg}$ were higher in the control (Table
3). In both evaluations (2009 and 2010), micronutrient contents were higher in the treatment with acaricide. However, only in 2009 there were significant differences between the groups (Table 4). The values of Fe did not show differences between the groups in any evaluations.

Table 3. Foliar macronutrientes for samples collected in February 2009 and 2010, six and seven years after the start of lime suphur applications, respectiveely.

\begin{tabular}{ccccccc}
\hline \multirow{2}{*}{ Groups } & $\mathbf{7}$ Macronutrients $\left(\mathbf{g ~ k g}^{-1}\right)(\mathbf{2 0 0 9})$ \\
\cline { 2 - 7 } & $\mathbf{N}$ & $\mathbf{P}$ & $\mathbf{K}$ & $\mathbf{C a}$ & $\mathbf{M g}$ & $\mathbf{S}$ \\
\hline Lime sulphur & $23.6 \mathrm{~b}$ & $1.3 \mathrm{~b}$ & $14.1 \mathrm{~b}$ & $23.1 \mathrm{a}$ & 1.6 & $4.0 \mathrm{a}$ \\
Control & $25.2 \mathrm{a}$ & $1.5 \mathrm{a}$ & $18.7 \mathrm{a}$ & $18.0 \mathrm{~b}$ & 1.8 & $2.8 \mathrm{~b}$ \\
\hline$F$-test & $6.2^{*}$ & $10.2^{* *}$ & $23.3^{* *}$ & $15.0^{* *}$ & $1.0^{\text {ns }}$ & $76.10^{* *}$ \\
C.V. $(\%)^{1}$ & 7.2 & 14,2 & 15.3 & 17.1 & 24.7 & 11.12 \\
\hline Groups & 25.8 & 1.8 & $17.6 \mathrm{~b}$ & 29.7 & $3.5 \mathrm{~b}$ & $2.8 \mathrm{a}$ \\
\hline Lime sulphur & 27.6 & 1.9 & $20.0 \mathrm{a}$ & 26.1 & $3.9 \mathrm{a}$ & $2.4 \mathrm{~b}$ \\
Control & $3.7^{\text {ns }}$ & $0.8^{\text {ns }}$ & $5.0^{*}$ & $3.6^{\text {ns }}$ & $7.5^{*}$ & $32.4^{* *}$ \\
\hline F-test & 9.6 & 18.1 & 15.6 & 18.9 & 11.0 & 7,8 \\
\hline C.V. $(\%)^{1}$ &
\end{tabular}

Averages followed by the different letter in the column differ significantly by $F$-test. ${ }^{1}$ Coefficient of variation. $(* *)$ significant at $1 \%$, and $(*)$ $5 \%$ of the probability.

Table 4. Results of foliar micronutrientes for samples collected in February 2009 and 2010.

\begin{tabular}{cccccc}
\hline \multirow{2}{*}{ Groups } & \multicolumn{5}{c}{ Micronutrientes $\left(\mathbf{g ~ k g}^{-1}\right)(\mathbf{2 0 0 9})$} \\
\cline { 2 - 6 } & $\mathbf{B}$ & $\mathbf{C u}$ & $\mathbf{F e}$ & $\mathbf{M n}$ & $\mathbf{Z n}$ \\
\hline Lime sulphur & $103.5 \mathrm{a}$ & $46.8 \mathrm{a}$ & 145.5 & $47.8 \mathrm{a}$ & $81.9 \mathrm{a}$ \\
Control & $82.9 \mathrm{~b}$ & $29.6 \mathrm{~b}$ & 136.6 & $40.0 \mathrm{~b}$ & $61.4 \mathrm{~b}$ \\
\hline$F$-test & $23.21^{* *}$ & $17.7^{* *}$ & $0.5^{\text {ns }}$ & $9.3^{* *}$ & $11.2^{* *}$ \\
C.V.(\%) & 12.2 & 28.3 & 23.3 & 15.5 & 22.7 \\
\hline Groups & \multicolumn{5}{c}{ Micronutrientes $\left(\mathbf{g ~ k g}^{-1}\right)(\mathbf{2 0 1 0})$} \\
\hline Lime sulphur & 124.1 & 25.1 & 135.9 & 37.7 & 48.2 \\
Control & 120.0 & 23.3 & 144.4 & 37.1 & 52.0 \\
\hline$F$-test & $0.5^{\text {ns }}$ & $0.2^{\text {ns }}$ & $0.4^{\text {ns }}$ & $0,0^{\text {ns }}$ & $0.2^{\text {ns }}$ \\
C.V. $(\%)^{1}$ & 13.1 & 51.8 & 26.4 & 34.4 & 45.6
\end{tabular}

Averages followed by the different letter in the column differ significantly by $F$-test. ${ }^{1}$ Coefficient of variation.

$(* *)$ significant at $1 \%$, and $(*) 5 \%$ of the probability.

Plants treated with lime sulphur had lower severities of citrus leprosis than control group in 2009 and 2010 (Figure 1A). Besides, fruit yield $\left(\mathrm{kg} \mathrm{ha}^{-1}\right)$ of lime sulphur group was higher in 2009 and 2010 (Figure 1B).

\section{Discussion}

In our study, it was clear that lime sulphur after seven years affects soil and plant properties, as soil $\mathrm{pH}$ in the most superficial layer showed marked differences in the plots treated. These may have occurred due to greater nutrient absorption by plants in lime sulphur group, as evidenced by an increase in productivity (Figure 1B). Higher productivity involves increased water absorption and extraction of nutrients from soil, which in turn may have contributed to keeping $\mathrm{pH}$ values low (CREWS et al., 2014). Besides, perennial crops extract an even higher proportion of nutrients from the soil to assign for fruit production (CREWS et al., 2014). The higher productivity in the lime sulphur group was attributed to the control of citrus leprosis mite (Figure 1). 


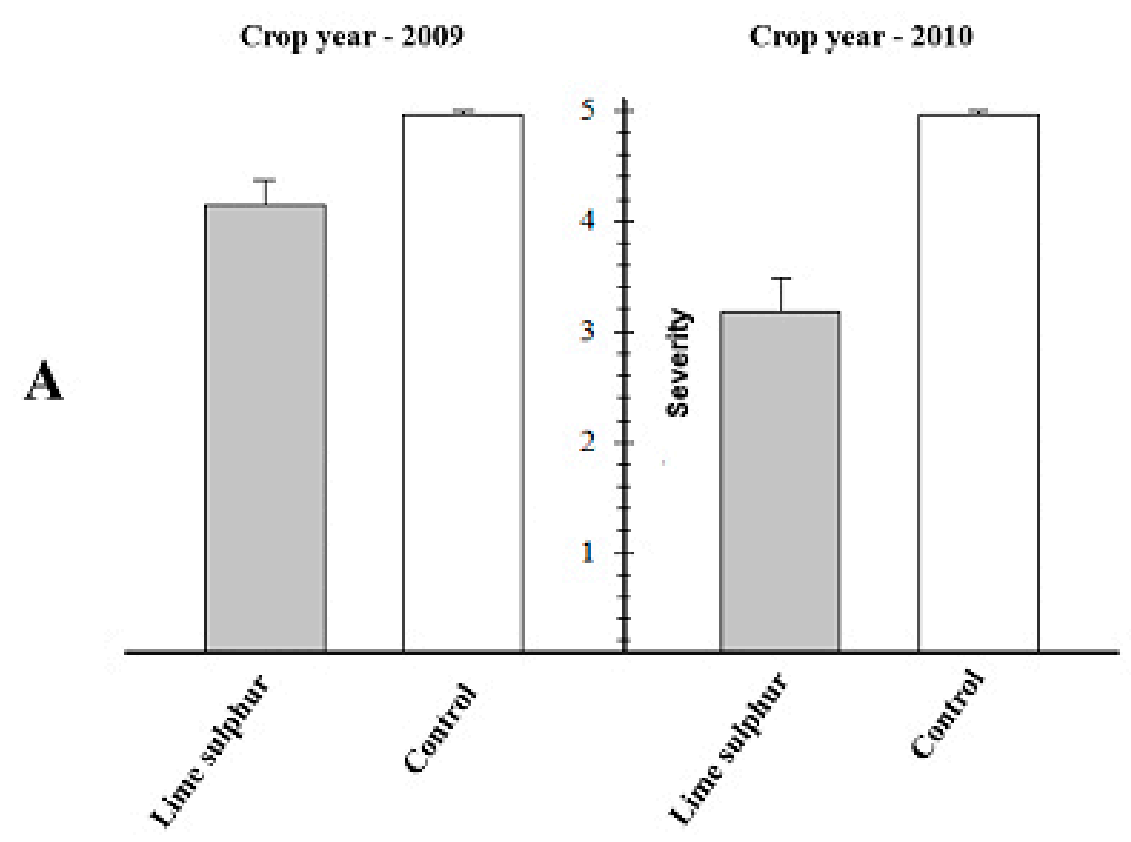

Crop year - 2009

Crop year - 2010

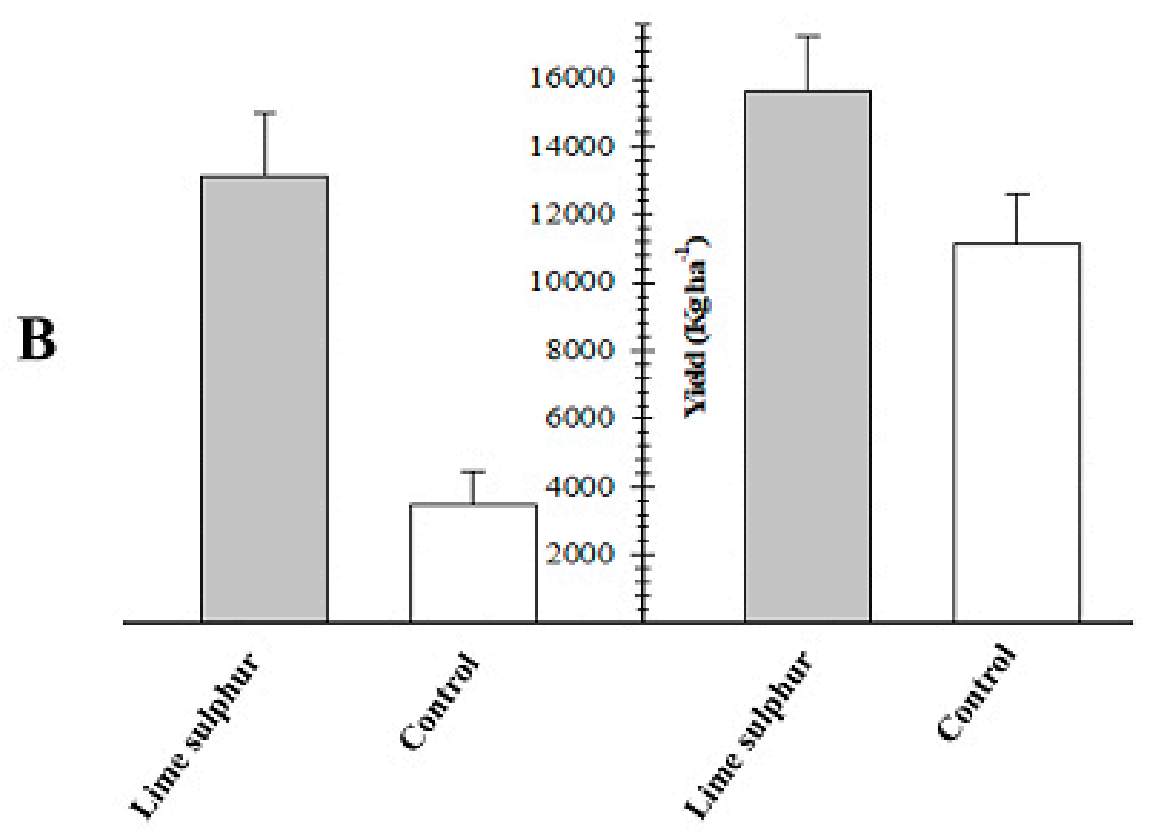

Figure 1. A) Citrus leprosis severity in plants of experimental groups lime sulphur and control in the crop years 2009 and 2010. B) Orange productivity $\left(\mathrm{kg} \mathrm{ha}^{-1}\right)$ in plants of experimental groups lime sulphur and control in the crop years 2009 and 2010. 
Another possible explanation for the decrease in $\mathrm{pH}$ in the lime sulphur group refers to elementary sulphur $\left(\mathrm{S}^{\circ}\right)$ present in this pesticide. Several studies have shown that elementary sulphur reduces soil pH (FUENTE et al., 2007; STAMFORD et al., 2007; HEYDARNEZHAD et al., 2012; KARIMIZARCHI et al., 2014; ARAÚJO et al., 2015). Turan et al. (2013) also verified that addition of sulphur in soil decreased $\mathrm{pH}$ and increased electrical conductivity while increased available of Mn. Ngatunga et al. (2003), in Tanzania, verified soil $\mathrm{pH}$ reduction with the use of sulfur for 12 years to control powdery mildew, a disease caused by Oidium anacardii Noack in cashew nut plants.

According to Stamford et al. (2007) and Heydarnezhad et al. (2012), primarily $S^{o}$ oxidation occurs due to the action of bacterias of the genus Acidithiobacillus spp. and Thiobacillus spp. that oxidize $\mathrm{S}^{\circ}$ to $\mathrm{S}_{-} \mathrm{SO}_{4}{ }^{2-}$ and, after the reaction, with $\mathrm{H}^{+}$from the hydrolysis of water, produce sulphuric acid and decrease soil $\mathrm{pH}$. However, this process is slow and occurs in a gradual manner (CARRIÓN et al., 2008). Also, Kelleher et al. (2017) showed that elemental sulphur applied in the soil initially results in the production of $\mathrm{CO}_{2}$ through microbial respiration, followed by order of magnitude increase in the capture of carbon from the atmosphere.

We believe there was higher sulfur leaching to the subsoil in the lime sulphur group. Sulphur is present in the soil mainly in sulfate anion form being easily leached from the superficial layer to the subsoil. Besides that, the balance of charges in the subsoil can be positive due to lower values of $\mathrm{pH}$ and organic matter, which increases sulfate adsorption. In contrast, the cations $\mathrm{Ca}^{2+}$ and $\mathrm{Mg}^{2+}$ are mostly retained in the superficial layers (HEIJDEN et al., 2015). Araújo et al. (2015) found that applications of elementary sulphur $\left(\mathrm{S}^{\circ}\right)$, intending to recover a soil with high salinity and alkalinity (sandy loam saline-sodic soil), raised $\mathrm{Ca}$ and $\mathrm{Mg}$ concentration.

On the other hand, the organic matter levels were not affected by lime sulphur treatments, indicating the oxidation of sulphur probably did not affect organic matter decomposition. Similar results were obtained by Araújo et al. (2015). The pattern CEC in high depths $(20-40 \mathrm{~cm})$ is linked to higher leaching bases for the subsurface layer of soil caused by the S-SO4${ }^{2}$ - and not due to generation of negative charges on the soil (SIDI et al., 2015).

Regarding Mg, there was a difference between the groups. Lower values of $\mathrm{Mg}$ found in the lime sulphur group can be explained by the higher plant absorption. Furthermore, leaching may also have contributed to the lower values of this nutrient, especially due to high soil mobility (ARAÚJO et al., 2015). The same explanation may be related to total acidity $(\mathrm{H}+\mathrm{Al})$. As the bases leach out or are taken up by plants from the soil, they are released from the surface of the colloids to the solution and, as a result, there is an entry of acid cations, particularly $\mathrm{H}^{+}$at the surface of colloids increasing the $\mathrm{H}+\mathrm{Al}$.

The results confirmed the highest concentrations of $\mathrm{Ca}$ and $\mathrm{S}$ in leaves of plants treated with lime sulphur. Certainly, this fact is explained by the high concentration of these elements in the lime sulphur formulation $(20 \%$ $\mathrm{S}$ and $8 \% \mathrm{Ca}$ ). In contrast, the lower levels of the macronutrients $\mathrm{N}, \mathrm{P}$, and $\mathrm{K}$ quantified in the lime sulphur group can be explained by the higher export of nutrients along with the fruits.

Plants treated with lime sulfur presented higher levels of micronutrients in their leaves. So, this product can have changed the rate of nutrient absorption via leaf. In citrus plants, the most part of micronutrients are mainly absorbed by leaves and not by roots (MATTOS JUNIOR et al., 2005; MATTOS JUNIOR et al., 2018). On the other hand, severity of citrus leprosis affects the nutrients foliar concentration (NOGUEIRA et al. 1996) (Figure 1B). These authors found that leaves of plants with symptoms of citrus leprosis had lower levels of $\mathrm{N}$ and higher levels of $\mathrm{Ca}, \mathrm{S}$, and $\mathrm{Fe}$. However, they also found that plants with and without citrus leprosis have similar levels of $\mathrm{P}, \mathrm{K}, \mathrm{Mg}$, $\mathrm{Cu}, \mathrm{Mn}, \mathrm{Zn}$ and B. Citrus leprosis causes dry of branches, and this affects the nutrient translocation (BASTIANEL et al., 2010). Therefore, we believe in our experiment citrus leprosis was the factor that most affected plant nutrition.

\section{Conclusions}

We conclude that management of $B$. yothersi using lime sulphur after a long period of time can cause chemical soil changes and affect plant nutrition. This acaricide reduced the $\mathrm{pH}$ values in $\mathrm{CaCl}_{2}$ and increased the levels of $\mathrm{S}_{-} \mathrm{SO}_{4}^{2-}$ in subsurface layers of the soil. Plants treated with lime sulphur had the highest leaf concentrations of $\mathrm{Ca}$ and $\mathrm{S}$ and of the micronutrients $\mathrm{B}, \mathrm{Cu}, \mathrm{Mn}$ e $\mathrm{Zn}$. However, the use of lime sulphur has a positive effect on citrus productivity because it helps in the management of citrus leprosis. Given its low cost and good receptivity by organic agriculture this product may be of great interest for growers. However, their full environmental effect must continue to be evaluated in a broad spectrum to understand their influence in agroecosystems.

\section{Acknowledgements}

The authors thank FAPESP (São Paulo Research Foundation) for the scholarship to the first author (grant number: 09/50245-4). Special thanks to Fundecitrus (Fund for Citrus Protection) by financial support and Branco Peres Agribusiness Group for providing the experimental area. 


\section{References}

ABBOT, C.E. The toxic gases of lime-sulphur. Journal of Economic Entomology, Lanham, v.38, n.5, p.618-620, 1945.

ANDRADE, D.J.; PATTARO, F.C.; OLIVEIRA, C.A.L. Resíduos de calda sulfocálcica sobre a eficiência de acaricidas no controle de Brevipalpus phoenicis. Ciência Rural, Santa Maria, v.41, n.10, p.1695-1701, 2011.

ANDRADE, D.J.; OLIVEIRA, C.A.L.; PATTARO, F.C.; SIQUEIRA, D.S. Acaricidas utilizados na citricultura convencional e orgânica: manejo da leprose e populações de ácaros fitoseídeos. Revista Brasileira de Fruticultura, Jaboticabal, v.32, n.4, p.1028-1037, 2010.

ARAÚJO, J.L.; SEVERO, P.J.S.; LUCENA, F.T.C.; VERIATO, R.G.; PAIVA, K.F. Enxofre elementar ou sulfato de cálcio para remediação de solos salino-sódicos? Pesquisa Agropecuária Tropical, Goiânia, v.45, n.4, p.388-396, 2015.

BARBOSA, J.C.; MALDONADO JR, W. AgroEstat. Sistema para análises estatísticas de ensaios agronômicos. Versao 1.0. Jaboticabal: FCAV/UNESP, 2010 .

BASTIANEL, M.; NOVELLI, V.M.; KITAJIMA, E.W.; KUBO, K.S.; BASSANEZI, R.B.; MACHADO, M.A.; FREITAS-ASTÚA, J. Citrus leprosis: centennial of an unusual mite-virus pathosystem. Plant Disease, Eagan, v.94, n.3, p.284-292, 2010.

CARRIÓN, C.; ABAD, M.; FORNES, F.; NOGUERA, V.; PUCHADES, R.; MAQUIEIRA, A.; GARCÍA, R. Acidification of composts from agricultural wastes to prepare nursery potting mixtures. ISHS Acta Horticulturae, Korbeek-Lo, v.779, p.333-340, 2008.

CREWS, T.E.; BROOKES, P.C. Changes in soil phosphorus forms through time in perennial versus annual agroecosystems. Agriculture Ecosystems and Environment, Amsterdam, v.184, p.168-181, 2014.

EMBRAPA. Sistema brasileiro de classificação de solos. Brasília: Embrapa Solos, 2013.
FUENTE, R.G.; CARRIÓN, C.; BOTELLA, S.; FORNES, F.; NOGUERA, V.; ABAD, M. Biological oxidation of elemental sulphur added to three composts from different feedstocks to reduce their $\mathrm{Ph}$ for horticultural purposes. Bioresource Technology, Amsterdam, v.98, n.18, p.3561-3569, 2007.

HEIJDEN, G.; DAMBRINE, E.; POLLIER, B.; ZELLER, B.; RANGER, J.; LEGOUT, A. Mg and Ca uptake by roots in relation to depth and allocation to aboveground tissues: results from an isotopic labeling study in a beech forest on base-poor soil. Biogeochemistry, New York, v.122, n.2-3, p.375-393, 2015.

HEYDARNEZHAD, F.; SHAHINROKHSAR, P.; SHOKRI, V.H. Influence of elemental sulphur and sulphur oxidizing bacteria on some nutrient deficiency in calcareous soils. International Journal of Agriculture and Crop Sciences, London, v.4, n.12, p.735-739, 2012.

HOLB, I.J.; DE JONG, P.F.; HEIJNE, B. Efficacy and phytotoxicity of lime sulphur in organic apple production. Annals of Applied Biology, Medford, v.142, n.2, p.225233, 2003.

KARIMIZARCHI, M.; AMINUDDIN, H.; KHANIF, M.Y.; RADZIAH, O. Elemental sulphur application and sweet maize (Zea mays L.) response in a high $\mathrm{pH}$ soil of Malaysia. Malaysian Journal of Soil Science, Serdang, v.18, n.1, p.75-86, 2014.

KELLEHER, B.P.; FLANAGAN, P.V.; HART, K.M.; SIMPSON, A.J.; OPPENHEIMER, S.F.; MURPHY, B.T.; O'REILLY, S.S.; JORDAN, S.F.; GREY, A.; IBRAHIM, A.; ALLEN, C.C.R. Large perturbations in $\mathrm{CO} 2$ flux and subsequent chemosynthesis are induced in agricultural soil by the addition of elemental sulphur. Scientific Reports, New York, v.7, n.1, p.4732, 2017.

KÖEPPEN,W. Roteiro para classificação climática. [s.1.], 1970.

MALAVOLTA, E.; VITTI, G.C.; OLIVEIRA, S.A. Avaliação do estado nutricional das plantas: princípios e aplicações. Piracicaba: Potafós, 1997. 319p. 
MATTOS JUNIOR, D.; BATAGLIA, O.C.; QUAGGIO, J.A. Nutrição dos citros. In: MATTOS JUNIOR, D.; DE NEGRI, J.D.; PIO, R.M.; POMPEU JUNIOR, J. Citros. Campinas: Instituto Agronômico, 2005.p .197-219.

MATTOS JUNIOR, D.; MACEDO, L.O.; HIPPLER, F.W.R.; BOARETTO, R.M.; QUAGGIO, J.A.; STIPP, S.R. Avanços na nutrição de citros e café. Informações Agronômicas, Piracicaba, n.163, p.1-11, 2018.

MINEIRO, J.L.C.; SATO, M.E.; NOVELLI, V.M.; ANDRADE, D.J. Distribuição de Brevipalpus yothersi Baker, 1949 (Acari: Tenuipalpidae) em diferentes hospedeiras e localidades no estado de São Paulo. Biológico, São Paulo, v.77, n.2, p.73-111, 2015.

NGATUNGA, E.; DONDEYNE, S.; DECKERS, J.A. Is sulphur acidifying cashew soils of South Eastern Tanzania? Agriculture Ecosystems and Environment, Amsterdam, v.95, n.1, p.179-184, 2003.

NOGUEIRA, N.L.; RODRIGUES, J.C.V.; CABRAL, C.P.; PRATES, H.S. Influence of leprosis on the mineral composition of Citrus sinensis leaves. Scientia Agricola, Piracicaba, v.53, n.2-3, p.354-355, 1996.

PATTARO, F.C. Calda sulfocálcica no agrossistema citrícola. 2003. Dissertação (Mestrado) - Universidade Estadual Paulista, Faculdade de Ciências Agrárias e Veterinárias, Jaboticabal, 2003.

RODRIGUES, J.C.V. Relações patógeno-vetor-planta no sistema leprose dos citros. 2000. Tese (Doutorado) Universidade de São Paulo, Escola Superior de Agricultura Luiz de Queiroz, Piracicaba, 2000.

RODRIGUES, J.V.C.; KITAJIMA, E.W.; CHILDERS, C.C.; CHAGAS, C.M Citrus leprosis virus vectored by Brevipalpus phoenicis (Acari: Tenuipalpidae) on citrus in Brazil. Experimental and Applied Acarology, Dordrecht, v.30, n.1-3, p.161-179, 2003.

SIDI, N.; ARIS, A.Z.; TALIB, S.N.; JOHAN, S.; YUSOFF, T.S.T.M.; ISMAIL, M.Z. Influential factors on the cation exchange capacity in sediment of Merambong Shoal, Johor. Procedia Environmental Sciences, Amsterdam, v.30, n.1, p.186-189, 2015.
SMILANICK, J.L.; SORENSON, D. Control of postharvest decay of citrus fruit with calcium polysulfide. Postharvest Biology and Technology, Amsterdam, v.21, n.2, p.157-168, 2001.

STAMFORD, N.P.; RIBEIRO, M.R.; CUNHA, K.P.V.; FREITAS, A.D.S.; SANTOS, C.E.R.S.; DIAS, S.H.L. Effectiveness of sulphur with Acidithio bacillus and gypsum in chemical attributes of a Brazilian sodic soil. World Journal of Microbiology and Biotechnology, New York, v.23, n.10, p.1433-1439, 2007.

TUELHER, E.S.; VENZON, M.; GUEDES, R.N.C.; PALLINI, A. Toxicity of organic-coffee-approved products to the southern red mite Oligonychus ilicis and to its predator Iphiseiodes zuluagai. Crop Protection, Amsterdam, v.55, n.1, p.28-34, 2014.

TURAN, M.A.; TABAN, S.; KATKAT, A.V.; KUCKYUNUK, Z. The evaluation of elemental sulphur and gypsum effect on soil $\mathrm{pH}$, EC, $\mathrm{SO}_{4}-\mathrm{S}$ and available Mn. Journal of Food, Agriculture and Environment, Helsinki, v.11, n.1, p.572-575, 2013.

VAN RAIJ, B.; ANDRADE, J.C.; CANTARELLA, H.; QUAGGIO, J.A. Análise química para avaliação da fertilidade de solos tropicais. O Agronômico, Campinas, v.53, n.1, p.32, 2001.

VENZON, M.; OLIVEIRA, R.M.; PEREZ, A.L.; RODRÍGUEZ-CRUZ, F.A.; MARTINS FILHO, S. Lime sulphur toxicity to broad mite, to its host plants and to natural enemies. Pest Management Science, New York, v.69, n.6, p.738-743, 2013. 